\title{
Research on the relationship between provincial foreign direct investment and economic growth: An empirical study in Indonesia
}

\author{
Bryna Meivitawanli \\ Binus Business School, Bina Nusantara University, \\ Indonesia \\ bryna.meivitawanli@binus.edu \\ ORCID 0000-0003-0891-5945
}

\begin{abstract}
The government of Indonesia has exerted a great deal of effort in attracting foreign investments into the country. The benefits of FDI are widely recognized, especially for developing countries, such as Indonesia. However, empirical studies have shown somewhat conflicting results. Many argued that FDI positively influences economic growth while others found otherwise. Therefore, this research seeks to determine the relationship between inward FDI and economic growth in Indonesia using panel data on the provinces from 2008 to 2017. Three absorptive capacities are included into the models. The models are tested using the random/fixed effects model and system GMM to tackle the endogeneity problem. The relationship between FDI and economic growth was found to be negative using both methodologies when the interaction term of FDI and human capital is introduced into the equation. The results are insignificant when the interaction term of FDI and human capital is excluded. This is against commonly held belief regarding FDI. The results of this research pose serious concerns for the government. It shows that strategies that are not based on empirical research might be misleading and harming the economy.
\end{abstract}

Keywords: absorptive capacities, FDI, human capital, Indonesia, System GMM.

JEL Classification: C33, F21, I25

\section{INTRODUCTION}

Foreign direct investment (FDI) has been empirically studied numerous times in the past. The literature shows that the nature of relationship between FDI and economic growth is far from univocal. On the surface, it seems that FDI should have a positive influence over economic growth for many reasons. Several of these reasons include technology spillover, increased total investment and development of local human capital or knowledge spillover. However, much of the empirical research did not come to this conclusion. In order to explain such results, scholars included other relevant factors that might support the proclaimed benefits of FDI. Examples of these supporting factors are human capital, financial market development and trade openness. Human capital is often presented by researchers as the key factor in strengthening or 
actualizing the positive influence of FDI on economic growth. Many researchers suggested and empirically found that human capital is an important variable in the relationship between FDI and economic growth. Another variable that is commonly discussed is the condition of local financial markets or the strength of the local financial institutions. Alfaro, Chanda, Kalemli-Ozcan and Sayek (2004) empirically studied the role of financial markets in bridging FDI and economic growth. The results showed that FDI affects economic growth positively only when host countries have well-developed financial markets. This result is similar to those in other articles that suggest FDI alone does not positively affect economic growth unless certain prerequisites are satisfied by a host country.

It is also interesting to see that most empirical studies made use of cross-country data spanning over a long period of time. These panel data are robust, and they incorporate a large number of observations. However, the results are at best generalized for the whole world, developing countries or a specific region such as Latin America or the Middle East. Although larger data sets produce better empirical research, the results may be not directly applicable to particular countries. As mentioned by Li and Liu (2005) and Blomström and Kokko (1996), the impact of FDI varies across countries. Therefore, it is not recommended to directly apply the results of a cross-country analysis to any country included in that dataset. Therefore, instead of performing a cross-country analysis, this paper is going to specifically study the relationship of FDI and economic growth in Indonesia. The results will contribute to literature as well as to Indonesian government policy-making as the data used are specific to Indonesia. The government should be confident that this research can be used as one of the bases to enact or retract FDI-related policies. Indonesia is chosen as the main subject of this research because it is a developing country and FDI is commonly seen as a way to help developing countries grow by learning from developed countries. Thus, it is more important to prove the positive contribution of FDI to economic growth in developing countries rather than developed ones. Another reason is because the current president of Indonesia, Joko Widodo, has been encouraging FDI since taking office. He is personally involved in many activities abroad with the intention of promoting Indonesia as a promising country for investments. This has resulted in many heated debates on whether he has taken the right steps in fostering Indonesia's economy. Yet, these debates remain theoretical without a solid base for empirical data analysis. The lack of research on the relationship between FDI and economic growth specifically in Indonesia is the final reason why Indonesia was chosen to be analyzed in this paper. This paper has taken a step further by not only taking time-series data but also panel data on Indonesian provinces. This deepens the analysis of Indonesia and provides results that can be used to induce or reduce FDI-supporting policies. The empirical results from the panel data on 180 cities in China, 1990 to 2002, showed evidence of spatial dependence on economic development (Madariaga \& Poncet, 2007). This kind of information is also important for Indonesia since Indonesia is similar to China in that certain parts of Indonesia are considerably more developed than the rest of the country. This affects regional policies that should be enacted in Indonesia.

Furthermore, one of the widely discussed concerns on this topic is the endogenous relationship between FDI and economic growth. Countries with higher economic growth attract more FDI; thus, the relationship is not one-way but simultaneous. The endogenous relationship was also empirically supported by $\mathrm{Li}$ and Liu (2005). They found that the relationship is increasingly endogenous. This paper addresses this issue, since this is also an important aspect of FDI that has not been deeply discussed, analyzed, or tested in much of the literature so far with the exception of Li and Liu (2005). 


\section{LITERATURE REVIEW}

One of the main variables in this paper is FDI. The definition of FDI and the theories behind the existence of FDI is first explained. Then, the relationship between FDI and economic growth is discussed. Much of the literature suggests that FDI has a positive influence on economic growth as long as several absorptive capacities are present. Several of these factors are also discussed. Last but not least, the endogeneity problem surrounding this relationship is discussed.

\subsection{Foreign direct investment}

Since FDI has been a hot-button issue for decades, well-established organizations have drawn up their consensus on the definition of FDI. The benchmark definition of FDI published by the Organisation for Economic Co-operation and Development (OECD) in 2008 stated that FDI is the objective of establishing a lasting interest by a resident enterprise in one economy, direct investor, in an enterprise, direct investment enterprise, that is resident in an economy other than that of the direct investor. Moreover, it is indicated that the relationship should be long-term and that there should be a significant degree of influence on the enterprise management. The evidence should be direct or indirect ownership of $10 \%$ or more of the voting power (OECD, 2008). This definition is widely acknowledged as it is aligned with the definition given by the International Monetary Fund (IMF) in its Balance of Payments Manual. The two definitions are acknowledged worldwide by all parties including academics.

Many researchers have tried to establish theories or models behind the growing evidence of FDI. After international trade came into the picture, FDI began to grab the attention of more and more people. The rise of multinational companies building their factories abroad and maintaining long-term investments led academics to wonder about the reasons behind this phenomenon. Numerous theories have developed over time. Some literature has categorized these into theories that assume perfect markets and theories that assume imperfect markets (Moosa, 2002; Nayak \& Choudhury, 2014; Agarwal, 1980; Lizondo, 1991). However, the classifications of FDI theories based on the assumption of the nature of markets are sometimes overlapping (Moosa, 2002). Some researchers categorized FDI into macroeconomic FDI theories and microeconomic FDI theories (Makoni, 2015; Denisia, 2010). Among many theories in the field of FDI, there are four commonly discussed theories, which are: product life cycle; internalization theory; capital market theory and the most widely discussed theory, the eclectic paradigm.

\subsection{Relationship between FDI and economic growth}

As previously mentioned, FDI has been comprehensively studied, but there are conflicting views regarding FDI and its relationship with economic growth. These results are discussed in detail in this section. There are several reasons behind the view that FDI contributes positively to economic growth. One of the theories which supports FDI is the new growth theory. This is because the new growth theory stresses the importance of technology, productivity, and efficiency in order to encourage growth (Ewe-Ghee, 2001). This leads to the reasons why FDI can induce economic growth. Some of the widely-known reasons are technology spillover, knowledge spillover and crowding in effect. Technology spillover is often discussed and studied in the literature of FDI since it is seen as an important way for FDI to bolster economic growth. As mentioned before, the new growth theory also points out the significance of technology for growth. FDI is viewed as a medium to transfer more advanced technology from developed countries to developing countries. By transferring high-end technology, foreign firms help increase the efficiency and productivity of domestic firms. Increased efficiency and productivity will then make the whole economy grows. These 
arguments are supported by empirical research that established the existence of technology spillover from FDI (Branstetter, 2006; Behera, Dua \& Goldar, 2012; Cheung \& Lin, 2004; Liu, 2002).

Moreover, foreign firms do not only cause technology spillover but also knowledge spillover. Knowledge does not necessarily mean technical know-how but can also include managerial techniques and strategic input. This kind of soft knowledge is crucial for domestic firms. Problems that local firms face might not only lie on limited technology but also lack of managerial skills. Some ways knowledge can be transferred are similar to how technology spills over. It can be transferred through communication with local suppliers as well as simply being in the area as local firms observe the way foreign firms manage their companies and employees. FDI also creates what is known as the 'crowding in effect'. This effect has been extensively discussed in the past; however, there is also a controversy of whether FDI causes crowding in effect or the opposite, the 'crowding out effect'. Crowding in effect is when FDI increases domestic investment; thus, it increases the total amount of investment in the host country. Borensztein, De Gregorio, and Lee (1998) supported the existence of crowding in effect, though their empirical result was not very robust.

Apart from the theoretical benefits of FDI, there is much empirical research that has posited a positive effect of FDI on economic growth. Ridzuan, Ismail, and Che Hamat (2017) found a positive effect of FDI on economic growth in Singapore. The data spanned over four decades from 1970 to 2013. More recent support came from Sothan and Zhang (2017) who demonstrated that FDI had a growth impact in Cambodia. The study covered a time period of over three decades from 1980 to 2014. Support for FDI also came from Qatar according to a time series study for exactly two decades (1990 to 2010). The result showed that inward FDI and economic growth had a long-term interaction (Almfraji, Almsafir \& Yao, 2014). Much of the literature arrived at the same conclusion; however, the positive relationship between FDI and economic growth is far from certain. There are also negative implications that FDI might cause. It is possible that FDI simply has no effect or insignificant effect on economic growth. The naysayers of FDI normally come from empirical research that did not find any significant effect of FDI on economic growth. There is also literature which found negative effects brought by FDI such as the crowding out effect.

Lin (2002) believed that the crowding out effect could happen in China. However, this reason was not empirically supported as Cheung and Lin (2004) did not support the existence of this effect in China. They suggested that the crowding out effect might be present in China, but it is not significant, nor is it overshadowed by the positive effect of FDI. This effect is discussed in terms of innovation and not economic growth, but the new growth theory includes technological aspect, therefore the innovation rate has an indirect relationship with economic growth and therefore should be taken into account. Zekarias (2016) also did not find evidence of the crowding out effect in Eastern Africa. However, data from the United Kingdom suggested that the crowding out effect of FDI on domestic firms might exist in the short run since there was evidence of negative effect of inward FDI on productivity growth of domestic firms (Driffield, 2004). Another result showed that inward FDI on average negatively affects productivity of the host industry when vertically related FDI is considered, together with focal industry FDI in the US (Chung, 1998).

Although FDI has been seen as a way to encourage economic growth, many empirical studies do not support this view. Saqib, Masnoon, and Rafique (2013) even found that FDI negatively affects economic growth in Pakistan. Moreover, evidence in Tunisia could not support the existence of FDI growth effect based on a study covering 38 years from 1970 to 2008 (Belloumi, 2014). Evidence from China also showed similar results where FDI's effect on economic growth was not significant based on time series data from 1985 to 2003 (Zhao \& Du, 2007). A time series study in Serbia also showed that inward FDI did not significantly affect economic growth. The study covered a 12 year period from 2007 to 2018 (Vasa \& Angeloska, 2020). Another similar result was found in Latin America based on panel data of 22 Latin 
American countries from 1980 to 2006. The results showed that the effect of FDI on economic growth is only marginal (Vadlamannati \& Tamazian, 2009). There is also much literature that found no significant influence when FDI was studied independently. Nunnenkamp and Spatz (2003) found that FDI was positively related to economic growth only when the host country reached a certain level of development. This development was seen in terms of human capital and economic stability. The necessity of a minimum threshold shows that FDI does not always improve economic growth. Furthermore, Borensztein, et al. (1998), also empirically found that the effect of FDI on economic growth is dependent on the level of human capital of the host country. This dependency once again proved that FDI alone does not automatically increase economic growth.

Alfaro et al. (2004) stated that FDI alone has a rather ambiguous role in its relation to economic growth. It significantly affects economic growth in a positive manner when the host country has well-established financial markets. The authors even explicitly stated that FDI does not affect economic growth when analyzed individually. This result was supported by Azman-Saini, Law \& Ahmad (2010) who found that the effect of FDI on economic growth only exists when the host country has exceeded a certain threshold of financial market development. They specifically mentioned that the effect of FDI on economic growth does not exist until then. Agbloyor et al. (2013) likewise found significant complementarities and feedback between FDI and the financial market in Africa which in turns lead to development of a domestic banking system. Carkovic and Levine (2002) stated that FDI does not bring about independent positive influence on economic growth. The research used two databases and accounted for an endogenous relationship, country specific characteristics, and lagged dependent variables in the regression that seemed to be lacking from previous literature. Thus, the results were valid and statistically sound. The results show no significant effect. Since many of the empirical results suggest the necessity of other growth driving factors in the equation of FDI and economic growth, these supporting variables are discussed next.

\subsection{Absorptive capacities}

There are many factors included in the equation of FDI and economic growth. These factors are sometimes included as control variables or as variables that support the positive relationship between FDI and economic growth. Many factors were mentioned in previous literature; this research is going to focus on the three most frequently discussed factors. These three are human capital, financial market development and trade openness. These three have received great attention in past papers. They are seen to be the determining factors in bringing the positive influence of FDI on economic growth.

A highly comprehensive paper by Iamsiraroj and Ulubaşoğlu (2015) found that the two main factors that affected the relationship between FDI and economic growth were financial markets and trade openness. While converse to what much literature have found, schooling or human capital were not significant factors. However, since human capital is one of the most supported factors in the literature, it is still going to be discussed further in this paper. Iamsiraroj and Ulubaşoğlu (2015) claimed that their research provides conclusive proof since they covered 140 countries over 39 years from 1970 to 2009 . They also used an informed econometric analysis after considering 880 estimates in 108 published research articles.

Human capital has received fervent interest in the literature of FDI and economic growth. Many researchers found that the level of human capital in the host country is a crucial factor in establishing a positive relationship between FDI and human capital. Even in the literature that does not focus on human capital, they have found positive influences that human capital has brought upon FDI on economic growth. There is also literature that does not support the significance of human capital. However, the majority of the literature suggests that human capital is an important factor in the equation of FDI and economic growth. Borensztein, et al. (1998), empirically found that a certain level of human capital is necessary for the 
host country in order to absorb the benefits of FDI. If this threshold is not achieved, FDI does not contribute to economic growth. This paper is a highly cited paper with robust statistical results. The research used a cross-country regression framework including 69 developing countries spanning from 1970 to 1989. $\mathrm{Li}$ and Liu (2005) also stressed the importance of human capital, though they did not state that it is a necessary condition to be met. They found that FDI and economic growth has a positive correlation and that human capital, along with technological capacity and economic development, are important factors that support the FDI absorption capability of the host countries. The authors also found an endogenous relationship between FDI and economic growth which will be discussed later. Similar findings were found by Bengoa Calvo and Sanchez-Robles (2003). Their research suggested that a certain level of human capital is needed along with economic stability and a liberalized market in order for FDI to be absorbed by the host country. Carkovic and Levine (2002) stated that the impact of FDI on economic growth does not depend on the degree of human capital. This empirical research also used cross-country data. These results also received support from Africa, where Gui-Diby (2014) found that the level of human capital did not limit the effect of FDI on economic growth. Last but not least, the aforementioned comprehensive literature by Iamsiraroj and Ulubaşoğlu (2015) also did not support the benefit of human capital. It can once again be seen that the literature did not conclude. Therefore, there is a need to analyze one specific country in order to be able to at least come to a solid conclusion for one single country. This is more practical as the results can be used to help a country rather than performing more cross-country analysis that will only contribute to the debate.

Similar to human capital, a sound financial market is seen to be the driver of FDI's positive influence on economic growth. There are four articles that specifically studied the effect of financial market development on the relationship of FDI and economic growth. There are also many papers that include financial market variable, although it is not the main focus of their research. As mentioned before, Alfaro et al. (2004) found no significant relationship between FDI and economic growth in the absence of a welldeveloped financial market. A strong financial market was proven to be a determining factor in nourishing the positive effect(s) of FDI on economic growth. The empirical research was robust with different financial market indicators and endogeneity issues. It was further supported by Alfaro et al. (2010). The empirical research found that FDI exerts a stronger positive effect on economic growth in countries with better financial markets compared with those with poor financial markets. However, unlike previous research which solely focused on financial market, this research proved the importance of other factors. These factors are human capital and the type of goods with regards to the local market (complementary or substitute). Nevertheless, the researchers also put financial markets as their main concern. Although similar to what Alfaro et al. (2004) and Alfaro et al. (2010) found, Azman-Saini et al. (2010) mentioned a certain threshold level of financial market development that the host country has to achieve in order to realize the benefits of FDI on economic growth. This research involved a large amount of data covering 91 countries over three decades from 1975 to 2005 . The researchers also put financial market development as their main focus.

A recent piece of research by Iamsiraroj (2016) studied 124 cross-country data from 1971 to 2010 and determined that there is a positive relationship between FDI and economic growth. Moreover, there are three factors which are key determinants of FDI. Those three are labor force, trade openness and economic freedom. Much of the literature showed the importance of trade openness in absorbing the benefits of FDI. The most apparent example is the previously mentioned work by Iamsiraroj and Ulubaşoğlu (2015). In this paper they concluded that trade openness is one of the two crucial absorptive capacities. Thus, if the host country wants to acquire as many benefits as possible from FDI, the country should be open for trade. A well-known supporter of trade openness is a paper written by Balasubramanyam, Salisu, and Sapsford (1996). Their paper focused on trade policy regimes. They studied the effect of FDI on economic growth in developing countries which adopted export promoting (EP) or an import substituting (IS) strategy. The 
research covered 46 developing countries. Their research highlighted the importance of trade openness in actualizing the positive effect of FDI. As usual, there were also conflicting results as to the role of trade openness in the FDI and economic growth nexus. Gbakou, Jallab, and Sandretto (2009) investigated the impact of FDI on economic growth in Middle Eastern and North African countries (MENA). Their empirical results found that the existence of FDI growth effect does not depend on the level of trade openness, instead it depends on macroeconomic stability.

\subsection{Endogeneity problem}

The endogeneity problem has been discussed in much of the literature on the FDI growth nexus; some addressed this issue, while others did not. First of all, endogeneity can be defined as a correlation between the explanatory variables and the error term in a regression (Roberts \& Whited, 2013). There are several causes of endogeneity problems. The first problem is due to omitted variables or variables that should be included in the vector of explanatory variables but are not. One of the reasons why some variables are omitted is because of data unavailability. Therefore, instead of being inserted as one of the explanatory variables, these variables are included as the error term instead. The problem happens when these omitted variables are correlated with the explanatory variables in the equation. This is one type of endogeneity problem which causes inferences to break down (Roberts \& Whited, 2013).

Another cause of endogeneity is simultaneity. This is the kind of endogeneity problem which is frequently discussed in the literature of FDI and economic growth. It is when FDI affects economic growth but simultaneously countries with better economic growth also attract more FDI. This issue is specifically addressed by Li and Liu (2005) where they found that during the second part of their study period (1985 to 1999), the data showed a significant endogenous relationship. Thus, they used the 3SLS method. They also tested two separate equations, one in which economic growth acts as the dependent variable and another in which FDI acts as the dependent variable. Li and Liu (2005) is a rare study which focuses on the endogeneity problem. The other literature tends to simply address the endogeneity problem using lagged values of FDI (Borensztein, et al., 1998; Carkovic \& Levine, 2002). The existence of this endogenous relationship is also supported by Samad (2009) who found evidence of a bidirectional short run causal link between FDI and GDP. The third possible cause of endogeneity problems is measurement error. The reason for this measurement error is the discrepancy between the true variable of interest and the proxy (Roberts \& Whited, 2013). There are also several causes of these discrepancies; examples are human error and conceptual differences between the chosen proxies and the actual variable. These measurement errors can happen both to dependent as well as independent variables (Roberts \& Whited, 2013). There are many ways researchers have addressed this endogeneity problem. As mentioned before, a common way is to use the lagged values of FDI. However, research by Li and Liu (2005) paid much closer attention to the existence of an endogenous relationship between FDI and economic growth. They tackled the issue using deeper analysis and put the focus of their research on this endogenous relationship. They specifically focused on the second cause of endogeneity problem, which is simultaneity. This paper also pays close attention to the endogeneity problem and addresses the issue by using system GMM.

\section{METHODOLOGY}

There are two methodologies used in this research. The first is a random/fixed effects model. There are three assumptions that should be met in the random effects model; the first is the assumption that the individual-specific effect is a random variable which is not correlated with the explanatory variables for all time periods (past, current, and future) of the same individual. The second assumption is that the individualspecific effect has constant variance. Last but not least, it assumes that the regressors are not perfectly 
collinear including a constant and that all regressors except for the constant have non-zero variance and not too many extreme values (Schmidheiny, 2016). The fixed effects model eliminates some of the assumptions required by the random effects model. The first and second assumptions of random effects model are not needed in a fixed effects model. A fixed effects model assumes that the time-varying explanatory variables are not perfectly collinear and that they have non-zero within-variance as well as not too many extreme values (Schmidheiny, 2016). These two models are used because pooled OLS does not take panel structure of the data into account. The test that can be taken to see which estimator is more suitable is the Hausman test. However, these estimators are not without flaws. Therefore, a GMM estimator is also used in this research.

Generalized method of moments (GMM) is a statistical method which combines observed economic data with the information in population moment conditions to produce estimates of the unknown parameters of the economic model (Zsohar, 2012). This method has been used in FDI analyses before. GMM is tailored to the type of information used in economic models. It was introduced by Hansen and Singleton (1982) in a well-known article which has been cited by thousands of researchers over the years. GMM can be applied to time-series data, cross-sectional data and panel data. It is especially suitable to run data that has shorter time periods and more cross-sections. This is the case with the dataset used in this research as there are more than 20 provinces observed over a ten year period. The minimum time span for GMM estimation is five years (Meo, 2016); therefore, GMM can be used in this research. There are also several problems that GMM deals with. This sets it apart from other estimation methods. The first is that GMM eliminates serial correlation; it also eliminates heteroscedasticity, and it tackles the endogeneity problem. However, GMM also has some limitations. First, it does not take cross-sectional dependency and structural break into account. Moreover, it is not efficient for panel data with long time series (Meo, 2016). In the case of panel data, two GMM are normally used in empirical research. These two are difference GMM and system GMM. Both of these estimators have several assumptions. As these estimators are directed to deal with panel data, there are possibly arbitrarily distributed fixed individual effects. Moreover, GMM is also known as a dynamic panel data model, therefore the process may be dynamic. The meaning of dynamic in this case is that past figures might influence the current value of the dependent variable. The next assumption is that the explanatory variables might be endogenous. The method also allows for heteroscedasticity and serial correlation. GMM also assumes that the idiosyncratic disturbances are not correlated between individuals (Roodman, 2006).

Based on these assumptions, it can be seen that GMM is quite powerful as it does not require assumptions that have to be satisfied in the previously discussed methods. Apart from those assumptions, GMM also allow some regressors to not be strictly exogenous, which means that it can be affected by past figures. Furthermore, GMM does not require long time series. Lastly, it allows for internal instruments such as lags of the instrumented variables (Roodman, 2006). Difference GMM was developed by Arellano and Bond in 1991. Difference GMM counters the issue of endogeneity by removing fixed effects, normally by applying the first difference transformation. However, this makes gaps in unbalanced panels larger (Meo, 2016). As there are certain limitations of difference GMM, in 1995, Arrelano and Bover developed system GMM, which was revised by Blundell and Bond in 1998 to become the system GMM used nowadays.

An important part of GMM is the existence of instrumental variables. These variables act as an agent to solve the endogeneity problem. Since it is difficult to find external instrumental variables, as previously mentioned, GMM allows for internal instrumental variables. The word internal in this case means that the instruments used are drawn from existing datasets. Lagged values of the endogenous variables are normally used as instrumental variables in this case. The minimum lag is 2 and it can extend to deeper lags. There are two requirements of a good instrumental variable. The first is that it must correlate with the included endogenous variables and second, it should be orthogonal to the error process (Baum, Schaffer \& Stillman, 
2003). In another words, it is important for the instrumental variable to be exogenous (Roodman, 2006). There are certain tests that can be taken to ensure that the instrumental variables are valid. When the instrumental variables used are valid, GMM estimations should be efficient especially in tackling the endogeneity issue. One of the tests to make sure that the instrumental variables are exogenous is the Hansen test for overidentifying restrictions (Hansen, 1982). This test is the minimized value for an efficient GMM estimator. This test is similar to the Sargan test (Sargan, 1958) and these two tests are consistent in nonrobust GMM. However, the Sargan test becomes inconsistent in robust one-step GMM, while the Hansen test stays consistent in two-step GMM (Roodman, 2006). Therefore, the Hansen test is going to be the focus in this research, but test results of these two are both reported. Furthermore, there is also an autocorrelation test called Arrelano-Bond test for $\mathrm{AR}(1)$ and $\mathrm{AR}(2)$ in first differences that should also be satisfied. There are several statistical software packages that can perform GMM, however STATA is used in this research as it can perform system GMM. The calculation is done by using the xtabond2 syntax which was written by Roodman in 2006. This command also generates Sargan, Hansen, Arrelano-Bond AR(1) and $\mathrm{AR}(2)$ tests. The null hypotheses of all of these tests are desirable. Therefore, the higher $\mathrm{p}$-value results of these tests the better. Higher p-value indicates that the null hypothesis has failed to be rejected. This shows that the estimations are valid.

This research requires a large amount of secondary data. The data are collected from established statistical reports. The most important source of data is the Indonesian government statistical bureau called Badan Pusat Statistik (BPS). This is the official bureau which collects statistical data on many aspects of Indonesia. Data on FDI and investment are taken from Indonesia's Investment Coordinating Board (Badan Koordinasi Penanaman Modal). Data on financial market development is taken from Indonesia's financial services authority (Otoritas Jasa Kenangan); this data used to be published by Indonesia's central bank before taken over by the financial services authority. The summary of data sources is shown in table 1.

Table 1

Data sources of variables

\begin{tabular}{|l|l|}
\hline Variables & Data Sources \\
\hline Economic Growth & Central Bureau of Statistics (BPS) \\
\hline Foreign Direct Investment & Investment Coordinating Board (BKPM) \\
\hline GDP & Central Bureau of Statistics (BPS) \\
\hline Population & Central Bureau of Statistics (BPS) \\
\hline Human Capital & Central Bureau of Statistics (BPS) \\
\hline Investment & Investment Coordinating Board (BKPM) \\
\hline Financial Market Development & Financial Services Authority (OJK) \& Central Bank (BI) \\
\hline $\begin{array}{l}\text { Trade Openness } \\
\text { Infrastructure }\end{array}$ & $\begin{array}{l}\text { Central Bureau of Statistics (Computation) } \\
\text { Central Bureau of Statistics (BPS) }\end{array}$ \\
\hline
\end{tabular}

Source: Authors' results.

\section{EMPIRICAL RESULTS AND DISCUSSION}

Five models are proposed in this paper. These five models are tested using two methodologies that have been discussed before. The five models are listed below.

$$
g_{i, t}=\beta_{0}+\beta_{1} \operatorname{lnyi}, 0+\beta 2 \mathrm{POP}_{\mathrm{i}, \mathrm{t}}+\beta 3 \mathrm{HC}_{\mathrm{i}, \mathrm{t}}+\beta 4 \mathrm{INV}_{\mathrm{i}, \mathrm{t}}+\beta 5 \mathrm{FDI}_{\mathrm{i}, \mathrm{t}}+\mathrm{BX}_{\mathrm{i}, \mathrm{t}}+\mathrm{e}
$$

This equation is taken from Li and Liu (2005), who in turn adopted this specification from Barro and Lee (1993) as this equation has been empirically tested before. FDI represents inward FDI, g represents economic growth, HC represents human capital, FIN represents financial market development and e represents the error term. yi,0 is the real GDP per capita in the beginning (2007), POP represents the population growth and INV represents the investment ratio. $\mathrm{X}$ includes many other variables that are also 
considered as determinants of growth such as infrastructure. $\beta$ is used to represent the coefficient. Since the type of data that is used in this analysis is panel data, therefore there are two subscripts for each of the variables. The first subscript, $i$ indicates the cross-section data, in this case each province. The second subscript, $t$ represents the time series data, in this case is the year of observation that is included in the analysis.

$\mathrm{g}_{\mathrm{i}, \mathrm{t}}=\beta_{0}+\beta_{1} \ln _{\mathrm{i}, 0}+\beta_{2} \mathrm{HC}_{\mathrm{i}, \mathrm{t}}+\beta_{3} \mathrm{FDI}_{\mathrm{i}, \mathrm{t}}+\beta_{4}\left(\mathrm{FDI}_{\mathrm{i}, \mathrm{t}} \mathrm{x} \mathrm{HC}_{\mathrm{i}, 0}\right)+\mathrm{BX}_{\mathrm{i}, \mathrm{t}}+\mathrm{e}$

As the first proposed absorptive capacity, the interaction form of FDI and human capital is included in this hypothesis. In order to simplify the equation, population and investment are included in the $\mathrm{X}$ variable since these two are not the main focus of this research. In this equation, the notations stand for the variables which have been introduced in the previous hypothesis.

$\mathrm{g}_{\mathrm{i}, \mathrm{t}}=\beta_{0}+\beta_{1} \mathrm{ln}_{\mathrm{y} i, 0}+\beta_{2} \mathrm{HC}_{\mathrm{i}, \mathrm{t}}+\beta_{3} \mathrm{FIN}_{\mathrm{i}, \mathrm{t}}+\beta_{4} \mathrm{FDI}_{\mathrm{i}, \mathrm{t}}+\beta_{5}\left(\mathrm{FDI}_{\mathrm{i}, \mathrm{t}} \mathrm{x} \mathrm{FIN}_{\mathrm{i}, 0}\right)+\mathrm{BX}_{\mathrm{i}, \mathrm{t}}+\mathrm{e}$

In the third hypothesis, the financial market indicator is introduced. Although financial market development was not in the original equation, the increasing attention drawn on the role of financial market in the relationship between FDI and economic growth validates its inclusion in the equation. This equation is similar to an equation which was empirically tested before by Alfaro et al. (2004). The notations once again described the variables that have been explained in the previous hypotheses.

$\mathrm{g}_{\mathrm{i}, \mathrm{t}}=\beta_{0}+\beta_{1} \ln _{\mathrm{yi}, 0}+\beta_{2} \mathrm{HC}_{\mathrm{i}, \mathrm{t}}+\beta_{3} \mathrm{TRADE}_{\mathrm{i}, \mathrm{t}}+\beta_{4} \mathrm{FDI}_{\mathrm{i}, \mathrm{t}}+\beta_{5}\left(\mathrm{FDIi}_{\mathrm{t}, \mathrm{x}} \mathrm{TRADE}_{\mathrm{i}, 0}\right)+\mathrm{BX}_{\mathrm{i}, \mathrm{t}}+\mathrm{e}$

Another new variable is introduced into the model, which is trade openness. As was extensively discussed in the literature review, there are three variables which are seen as influential in the FDI economic growth nexus. TRADEi,t represents the variable of trade openness.

$\mathrm{g}_{\mathrm{i}, \mathrm{t}}=\beta_{0}+\beta_{1} \ln _{\mathrm{y}, 0}+\beta_{2} \mathrm{HC}_{\mathrm{i}, \mathrm{t}}+\beta_{3} \mathrm{FIN}_{\mathrm{i}, \mathrm{t}}+\beta_{4} \mathrm{TRADE}_{\mathrm{i}, \mathrm{t}}+\beta_{5}\left(\mathrm{FDI}_{\mathrm{i}, \mathrm{t}} \mathrm{x} \mathrm{HC}_{\mathrm{i}, \mathrm{t}}\right)+\beta_{6}\left(\mathrm{FDI}_{\mathrm{i}, \mathrm{t}} \mathrm{x} \mathrm{FIN}_{\mathrm{i}, \mathrm{t}}\right)+\beta_{7}\left(\mathrm{FDI}_{\mathrm{i}, \mathrm{t}} \mathrm{x}\right.$

$\mathrm{TRADE}_{\mathrm{i}, \mathrm{t}}+\mathrm{BX}_{\mathrm{i}, \mathrm{t}}+\mathrm{e}$

The combined effect of all of the variables including the interaction terms of the three main supporting variables with FDI should also be tested to see whether there are any differences between the results of this equation and the previous ones. All of these variables have been introduced before; thus, no further clarifications on the notations are needed. Before going into the results of the two methodologies, a correlation matrix is shown in table 2 below. In the correlation matrix, it can be seen that all of the values shown are below 0.7. It shows that there is no problem of multicollinearity in the dataset (Dormann et al., 2013). Therefore, this dataset can be used for further analysis.

Table 2

\begin{tabular}{|c|c|c|c|c|c|c|c|c|c|}
\hline \\
\hline & G & FDIGDP & LNY & POP & $\mathrm{HC}$ & INV & FIN & INF & TRADE \\
\hline G & 1.000000 & 0.011641 & -0.229451 & -0.310469 & -0.019704 & -0.015411 & 0.137452 & 0.037828 & -0.035238 \\
\hline FDIGDP & 0.011641 & 1.000000 & -0.025201 & 0.052231 & -0.062286 & 0.156158 & 0.032933 & -0.047914 & 0.001159 \\
\hline LNY & -0.229451 & -0.025201 & 1.000000 & 0.307432 & 0.182333 & 0.010671 & 0.198195 & 0.485254 & 0.047675 \\
\hline $\mathrm{HC}$ & -0.019704 & -0.062286 & 0.182333 & -0.254476 & 1.000000 & 0.113943 & 0.190221 & 0.006758 & -0.306942 \\
\hline INV & -0.015411 & 0.156158 & 0.010671 & -0.125950 & 0.113943 & 1.000000 & -0.034956 & -0.150161 & 0.112987 \\
\hline FIN & 0.137452 & 0.032933 & 0.198195 & -0.301048 & 0.190221 & -0.034956 & 1.000000 & 0.628162 & 0.211575 \\
\hline INF & 0.037828 & -0.047914 & 0.485254 & 0.056224 & 0.006758 & -0.150161 & 0.628162 & 1.000000 & 0.268315 \\
\hline
\end{tabular}




\subsection{Fixed/Random effects model}

Both random effects and fixed effects are run for every model before performing a Hausman test. A Hausman test indicates which model is more suitable. Random or fixed effects models are shown next depending on the result of Hausman test. The results of Hausman test show that the random effects model is appropriate for all hypotheses. The p-value of the Hausman tests are 0.3550, 0.3963, 0.3724, 0.6832 and 0.2047 for models $1,2,3,4$, and 5, respectively. The p-values are all above $5 \%$ suggesting that the null hypotheses are all accepted. Therefore, the reported results in this paper are the random effects model for all hypotheses as shown in table 3.

Since most of the data are ratios, thus their values are relatively small. Therefore, the natural log value of GDP per capita is used instead of the nominal value in order to lessen the difference in value. The number of observation and probability of the random effects model for each hypothesis is also reported in table 3 below. It can be seen that the number of observation for hypotheses 4 and 5 are different due to the inclusion of trade openness variable that is only available for 23 out of 33 provinces. It can also be seen from the table that all p-values of the five models are below $5 \%$ suggesting that all models are significant. The standard errors are all robust to heteroscedasticity. Based on the results in table 3, FDI does significantly affect economic growth in equation 2 only and it is highly significant at a $1 \%$ confidence level. However, it shows no significant results in any of the other equations. The most interesting part of this result is that the coefficient is not positive but negative. This significant negative effect of FDI on economic growth is very surprising and has harmful consequences. A possible explanation of this is the occurrence of the crowding out effect where foreign investment reduces the total investment in the country as it reduced domestic investment due to tight competition. Negative coefficients are observed in many equations, although most of them suggest that FDI is not significant. Much of the literature suggests that the effect of FDI in the growth equation is only marginal depending on the situations (Belloumi, 2014; Zhao \& Du, 2007; Carkovic \& Levine, 2002; Alfaro, 2003; Kholdy \& Sohrabian, 2005; Johansson, 2015). In this case, the introduction of human capital might render the negative influence of FDI valid as a low level of human capital might harm the economy when combined with inward FDI as the local companies are not competent enough to compete with the foreigners, resulting in a crowding out effect that slows down the economy. The natural $\log$ of initial GDP shows significant results in all equations although it is significant at a different confidence level. Most of the results show significance at the 1\% confidence level. Similar to FDI, the coefficients are all negative. It shows that the lower the initial GDP, the faster the economy grows which is expected. This result is similar to previous research (Borensztein et al., 1998; Wang, 2003; Li \& Liu, 2005). Just like the natural $\log$ of GDP, population shows a negative significant effect on economic growth in all equations. Furthermore, the results are significant at a $1 \%$ confidence level. This is expected since the faster the population grows, the slower the economy grows as economic growth is proxied by real GDP per capita. This result also receives support from past literature (Azman-Saini, et al., 2010; Su \& Liu, 2016; Albatel, 2005; Ali, 2015).

The results for human capital are quite similar to the results of FDI. It is significant in equation 2 and 5 and its coefficients are all negative. This is rather surprising since many studies suggested that human capital affects economic growth in a positive manner. However, this result is supported by a study conducted in the European Union where countries, especially those focused on agriculture showed a negative effect of human capital on economic growth (Čadil, Petkovová \& Blatná, 2014). As mentioned in their paper, several possible explanations include the shift of people with higher education to other regions and the possibility of a change in demand, which in turn slows down growth. Another possible reason is a problem with the indicator used to proxy for human capital. There have been several articles that pointed out the importance of quality instead of quantity in education. A higher level of education does not mean an increased level of 
cognitive skills if the government pays no attention to the quality of the education provided (Ali, 2015; Čadil, et al., 2014; Hanushek \& Woessman, 2007). Domestic investment is the only variable that does not show any significant results in any of the equations. While infrastructure shows varying results, it is significant in all equations other than equation 4. However, it is significant at a different confidence level. Regardless, all of the coefficients are positive, which is expected as the better the infrastructure, the faster the economy should grow. This result is supported by previous literature (Huchet-bourdon, Le Mouël \& Vijil, 2011; Ali, 2017). All interaction terms in this analysis are not significant except for FDI and human capital. Interaction term of FDI and human capital show significant results whenever it is introduced into the equation and it is always significant at a $1 \%$ confidence level. The coefficients are also positive which show promising results. Interaction term of FDI and financial market development show similar results to the financial market development itself; both do not exert a significant effect on economic growth. Unlike financial market development, although interaction term of FDI and trade openness does not significantly affect economic growth. However, trade in itself significantly affects economic growth. Surprisingly, the coefficients are negative. These models were tested once again using system GMM.

Table 3

Random effects model of FDI-Economic growth nexus

\begin{tabular}{|c|c|c|c|c|c|}
\hline \multirow{2}{*}{$\begin{array}{l}\text { Explanatory } \\
\text { Variables }\end{array}$} & \multicolumn{5}{|c|}{ Dependent Variable: $g$} \\
\hline & (1) & (2) & (3) & (4) & (5) \\
\hline $\begin{array}{l}\text { Number of } \\
\text { obs. }\end{array}$ & 330 & 330 & 330 & 230 & 230 \\
\hline Prob $>$ F & 0.0000 & 0.0000 & 0.0000 & 0.0000 & 0.0000 \\
\hline Lny (initial) & $\begin{array}{c}-.0108884 * * * \\
(.0032822)\end{array}$ & $\begin{array}{c}-.0080003 * * * \\
(.0028724)\end{array}$ & $\begin{array}{c}-.0107545^{* * *} \\
(.0030804)\end{array}$ & $\begin{array}{c}-.0088919 * * * \\
(.0033467)\end{array}$ & $\begin{array}{l}-.0049004 * \\
(.0025166)\end{array}$ \\
\hline FDI & $\begin{array}{l}-.0009716 \\
(.5789714)\end{array}$ & $\begin{array}{c}-8.844439 * * * \\
(2.086601)\end{array}$ & $\begin{array}{l}-.1094476 \\
(1.027746)\end{array}$ & $\begin{array}{c}.1068441 \\
(.7763871)\end{array}$ & $\begin{array}{l}-.3736644 \\
(.4387826)\end{array}$ \\
\hline POP & $\begin{array}{c}-.7363956 * * * \\
(.1905742)\end{array}$ & $\begin{array}{c}-.9516165 * * * \\
(.1827462)\end{array}$ & $\begin{array}{c}-.7009585^{* * *} \\
(.1703582)\end{array}$ & $\begin{array}{c}-.8582128 * * * \\
(.2227929)\end{array}$ & $\begin{array}{c}-1.137285^{* * *} \\
(.1805609) \\
\end{array}$ \\
\hline HC & $\begin{array}{l}-.0003235 \\
(.0002615)\end{array}$ & $\begin{array}{c}-.0008523 * * * \\
(.0003027)\end{array}$ & $\begin{array}{l}-.0003456 \\
(.0002472)\end{array}$ & $\begin{array}{c}-.000222 \\
(.0003346)\end{array}$ & $\begin{array}{c}-.0010609 * * \\
(.0004456)\end{array}$ \\
\hline INV & $\begin{array}{c}.0135272 \\
(.0736089)\end{array}$ & $\begin{array}{c}.035752 \\
(.0738419)\end{array}$ & $\begin{array}{c}.0079199 \\
(.0777918)\end{array}$ & $\begin{array}{l}-.0077528 \\
(.0835001)\end{array}$ & $\begin{array}{l}-.0054145 \\
(.0792456)\end{array}$ \\
\hline INF & $\begin{array}{c}.0007718^{* * *} \\
(.0002929)\end{array}$ & $\begin{array}{l}.0005652^{*} \\
(.0002947)\end{array}$ & $\begin{array}{c}.0006203 \\
(.0003909)\end{array}$ & $\begin{array}{c}.0010683^{* * *} \\
(.0003767)\end{array}$ & $\begin{array}{l}.0009549 * \\
(.0005273)\end{array}$ \\
\hline FDIHC & & $\begin{array}{c}.1338942^{* * *} \\
(.0311648)\end{array}$ & & & $\begin{array}{c}.1662929 * * * \\
(.0439764)\end{array}$ \\
\hline FIN & & & $\begin{array}{c}.0067486 \\
(.0153185)\end{array}$ & & $\begin{array}{c}.0120071 \\
(.0093594)\end{array}$ \\
\hline FDIFIN & & & $\begin{array}{c}.3302268 \\
(2.474966)\end{array}$ & & $\begin{array}{l}-3.232423 \\
(.9587037)\end{array}$ \\
\hline TRADE & & & & $\begin{array}{l}-.0225302 * \\
(.0132774)\end{array}$ & $\begin{array}{c}.047558^{* * *} \\
(2.284512)\end{array}$ \\
\hline FDITTR & & & & $\begin{array}{l}-1.769781 \\
(3.604184)\end{array}$ & $\begin{array}{c}2.221544 \\
(4.722147)\end{array}$ \\
\hline Constant & $\begin{array}{c}.1738193^{* * *} \\
(.0335082)\end{array}$ & $\begin{array}{c}.1874186^{* * *} \\
(.0351039)\end{array}$ & $\begin{array}{c}.1728924 * * * \\
(.0329042)\end{array}$ & $\begin{array}{c}.1505425^{* * *} \\
(.036492)\end{array}$ & $\begin{array}{c}1734778^{* * *} \\
(434.8682)\end{array}$ \\
\hline
\end{tabular}

Source: Authors' results. * indicates significance level at 0.10 level, ** indicates significance level at 0.05 level, *** indicates significance level at 0.01 level. Heteroscedasticity-consistent standard errors in parentheses. 


\subsection{GMM estimator}

The inclusion of lagged value of dependent variable is commonly done in GMM estimations. Due to this inclusion, system GMM is more appropriate than difference GMM in this case. Therefore, all of the equations are going to be analyzed using system GMM. Robust estimations were performed. The results are shown in table 4. The instrumental variable that is used in this analysis is the second lag of FDI since FDI is the suspected endogenous variable in the equation. As discussed previously, lag of endogenous variable can be used as instrumental variables. Furthermore, second lag of population and infrastructure are also included since the test results show that the combination of these three variables are the most robust.

Table 4

System GMM Estimation Results of FDI-Growth Nexus

\begin{tabular}{|c|c|c|c|c|c|}
\hline \multirow{2}{*}{$\begin{array}{l}\text { Explanatory } \\
\text { Variables }\end{array}$} & \multicolumn{5}{|c|}{ Dependent Variable: $g$} \\
\hline & (1) & (2) & (3) & (4) & (5) \\
\hline $\begin{array}{l}\text { Number of } \\
\text { obs. }\end{array}$ & 297 & 297 & 297 & 207 & 207 \\
\hline Prob > F & 0.000 & 0.000 & 0.000 & 0.004 & 0.000 \\
\hline Lny & $\begin{array}{c}.004838 \\
(.0065486)\end{array}$ & $\begin{array}{l}.0001625 \\
(.0062355)\end{array}$ & $\begin{array}{l}.0066239 \\
(.0088493)\end{array}$ & $\begin{array}{l}.0034522 \\
(.0099219)\end{array}$ & $\begin{array}{c}.001676 \\
(.0139547)\end{array}$ \\
\hline L1. G & $\begin{array}{c}.262052 \\
(.1618297)\end{array}$ & $\begin{array}{l}.0982804 \\
(.2260216)\end{array}$ & $\begin{array}{c}.2642282 \\
(.1639067)\end{array}$ & $\begin{array}{l}.1889526 \\
(.242612)\end{array}$ & $\begin{array}{c}.0756699 \\
(.2828033)\end{array}$ \\
\hline FDI & $\begin{array}{l}.0328004 \\
(.9491283) \\
\end{array}$ & $\begin{array}{c}-20.73996 * * * \\
(7.052667)\end{array}$ & $\begin{array}{r}.8721149 \\
(1.061716) \\
\end{array}$ & $\begin{array}{l}-.7568199 \\
(1.096121) \\
\end{array}$ & $\begin{array}{c}-25.62543^{* *} \\
(10.14664) \\
\end{array}$ \\
\hline POP & $\begin{array}{l}. .5842186 \\
(.372859)\end{array}$ & $\begin{array}{l}-1.12706^{* *} \\
(.5308513)\end{array}$ & $\begin{array}{c}-.482808 \\
(.4692785)\end{array}$ & $\begin{array}{c}-.5145109 \\
(.30312)\end{array}$ & $\begin{array}{l}.9031428^{*} \\
(.4451268)\end{array}$ \\
\hline HC & $\begin{array}{l}-.0004691 \\
(.0003384)\end{array}$ & $\begin{array}{c}-.0018372 * * * \\
(-.0018372)\end{array}$ & $\begin{array}{l}.0004504 \\
(.0002981)\end{array}$ & $\begin{array}{l}.0006008 \\
(.0008754)\end{array}$ & $\begin{array}{c}-.0031049 * * \\
(.0013976)\end{array}$ \\
\hline INV & $\begin{array}{l}-.1913358 \\
(.2595118)\end{array}$ & $\begin{array}{l}-.2200142 \\
(.2498571)\end{array}$ & $\begin{array}{l}-.1762065 \\
(.2751326)\end{array}$ & $\begin{array}{c}.0383695 \\
(.3766667)\end{array}$ & $\begin{array}{c}.1541421 \\
(.4283747)\end{array}$ \\
\hline INF & $\begin{array}{c}.000064 \\
(.0005037)\end{array}$ & $\begin{array}{l}-.0005345 \\
(.0005509)\end{array}$ & & $\begin{array}{c}.0002051 \\
(.0010095)\end{array}$ & $\begin{array}{c}.0007798 \\
(.0013078)\end{array}$ \\
\hline FDIHC & & $\begin{array}{c}.3108758^{* * *} \\
(.111299)\end{array}$ & & & $\begin{array}{c}.4299032^{* *} \\
(.155767)\end{array}$ \\
\hline FIN & & & $\begin{array}{c}.0215021 \\
(.0346123)\end{array}$ & & $\begin{array}{c}.0917179 \\
(.0546976)\end{array}$ \\
\hline FDIFIN & & & $\begin{array}{l}-3.352026 \\
(5.026058)\end{array}$ & & $\begin{array}{c}-17.8228 \\
(10.94003)\end{array}$ \\
\hline TRADE & & & & $\begin{array}{l}-.0676629 \\
(.2630246)\end{array}$ & $\begin{array}{l}-.3252555 \\
(.3645953)\end{array}$ \\
\hline FDITTR & & & & $\begin{array}{c}13.94967 \\
(26.98509)\end{array}$ & $\begin{array}{c}42.75819 \\
(48.60747)\end{array}$ \\
\hline Constant & $\begin{array}{l}.1211714^{* *} \\
(.0458346) \\
\end{array}$ & $\begin{array}{c}.1913309^{* * *} \\
(.0608758)\end{array}$ & $\begin{array}{l}.128606^{* *} \\
(.066071)\end{array}$ & $\begin{array}{l}.1192403^{* *} \\
(.0592563) \\
\end{array}$ & $\begin{array}{l}.2703604 * * \\
(.1208533) \\
\end{array}$ \\
\hline AR (1) & 0.112 & 0.128 & 0.117 & 0.254 & 0.211 \\
\hline AR (2) & 0.614 & 0.517 & 0.599 & 0.542 & 0.369 \\
\hline Sargan test & 0.133 & 0.195 & 0.102 & 0.130 & 0.392 \\
\hline Hansen test & 0.958 & 0.978 & 0.945 & 0.999 & 1.000 \\
\hline
\end{tabular}

Source: Authors' results. * indicates significance level at 0.10 level, ** indicates significance level at 0.05 level, $* * *$ indicates significance level at 0.01 level. Heteroscedasticity-consistent standard errors in parentheses. 
The validity of these instrumental variables are tested using Sargan and Hansen tests. The number of observations for equation 4 and 5 are lower than the rest due to the inclusion of the trade openness variable that is only available for 23 provinces in Indonesia. The difference between the number of observations in this estimation and the random effects model is due to the inclusion of lagged variables, therefore one year's data of 33 provinces is subtracted from the total dataset. As explained previously, the desired results for all tests are acceptance of the null hypothesis. It can be seen from the table that all results of Arrelano-Bond $\mathrm{AR}(1)$ and $\mathrm{AR}(2)$ as well as Sargan and Hansen tests were above 0.05. All of them did not show any results below 0.1. Thus, it can be concluded that there is no autocorrelation in all the equations and all of the instrumental variables used are exogenous. These show the validity of the results.

The results show that there are no significant variables in equation 1,3 and 4 except for the constant. The rest of the variables show no significant results at all in any of these three equations. However, in equations 2 and 5, several variables (FDI, human capital and their interaction term) show a significant effect on economic growth. All are at a 1\% confidence level and 5\% confidence level in equations 2 and 5 , respectively. This is very interesting since these three variables are the only three that show some significant results, while the rest of the variables do not show any significant results in any of the equations other than population that is significant only at a $10 \%$ confidence level in equation 5. Even more interestingly, the coefficients of FDI and human capital individually are both negative while the interaction term shows a positive coefficient. These changes show that the introduction of human capital variable has a large effect on the equation. These results are the same as the results of the random effects model. This confirms that human capital is the appropriate absorptive capacity for Indonesia, which is supported by much of the previous literature (Borensztein, et al., 1998; Li \& Liu, 2005; Fadhil \& Almsafir, 2015; Solomon, 2011). But the main concern lies on the fact that FDI and human capital both negatively affect economic growth which might cancel out the positive effect of the interaction term. Initial output, population growth, infrastructure, and trade openness, which showed significant results in previous methodology lost their significance when system GMM was used. This might be due to the endogenous problem that is tackled by using this methodology.

\section{CONCLUSION}

This study was carried out to discover the relationship between FDI and economic growth in Indonesia using its provincial data. This is important since the Indonesian government led by the current president, Joko Widodo, has shown great support and gone the extra mile to encourage FDI into Indonesia. However, based on the results of this research, FDI is found to be either negatively related or not significantly related to economic growth. It means that the higher the FDI, the slower the economy is growing. This shows that the government is currently harming the economy instead of fostering it. This is a serious concern that must be addressed right away by the government. Common beliefs that FDI is good for the economy is not necessarily true for all developing countries; thus, conducting a single country analysis using panel data is important to make sure that government is taking the right actions to develop the country's economy. The study was conducted using two methodologies, which are fixed/random effects model and system GMM. A significant negative influence of FDI and human capital on economic growth is proven using both random effects model and system GMM. Both methodologies also prove that inward FDI does not significantly affect economic growth in equations where the interaction term of FDI and human capital is excluded. This indicates that the government can reallocate resources that are currently directed at attracting FDI to other aspects that will bring an actual positive influence on the economy. The government should also design strategies to increase the quality of education so that its people are equipped with necessary skills to absorb the benefits of FDI and help the economy grow, as human capital is the only absorptive capacity 
applicable to Indonesia. Researchers should also adopt a better proxy for human capital that focuses on quality instead of quantity. Overall, this research has both theoretical and practical contributions.

\section{ACKNOWLEDGEMENT}

The author is thankful to Bina Nusantara University for financial support.

\section{REFERENCES}

Acemoglu, D., Johnson, S., Robinson. I., Thaicharoen, Y. (2004). Institutional Causes. Macroeconomic Symptoms: Volatility. Crises and Growth. Journal of Monetary Economics, 50, 49-123.

Agarwal, J. P. (1980). Determinants of foreign direct investment: A survey. Weltwirtsch. Archive, 116(4), $739-773$.

Agbloyor, E. K., Abor, J., Adjasi, C. K. D., \& Yawson, A. (2013). Exploring the causality links between financial markets and foreign direct investment in Africa. Research in International Business and Finance, 28(C), 118-134. https://doi.org/10.1016/j.ribaf.2012.11.001

Albatel, A. H. (2005). Population growth and economic development in Saudi Arabia. Scientific Journal of King Faisal University, 6(2), 341-374. https://doi.org/10.1108/10264116200300007

Alfaro, L. (2003). Foreign direct investment and growth: Does the sector matter?. Harvard Business School, 1-32.

Alfaro, A. L., Chanda, S. Kalemli-Ozcan, \& Sayek, S. (2004). FDI and economic growth: The role of local financial markets. Journal of International Economics, 64(1), 89-112. https://doi.org/10.1016/S0022-1996(03)00081-3

Alfaro, L., Chanda, A., Kalemli-Ozcan, S., \& Sayek, S. (2010). Does foreign direct investment promote growth? Exploring the role of financial markets on linkages. Journal of Development Economics, 91, 242-256. https://doi.org/10.1016/j.jdeveco.2009.09.004

Ali, S., Alam, K. J., Islam, S., \& Hossain, M. (2015). An empirical analysis of population growth on economic development: The case study of Bangladesh. International Journal of Economics, Finance and Management Sciences, 3(3), 252. https://doi.org/10.11648/j.ijefm.20150303.21

Ali, W. (2017). The impact of trade openness on the economic growth of Pakistan: 1980-2010. Global Business and Management Research, 7(2).

Almfraji, M. A., Almsafir, M. K., \& Yao, L. (2014). Economic growth and foreign direct investment inflows: The case of Qatar. Procedia - Social \& Behavioral Sciences, 109, 1040-1045. https://doi.org/10.1016/j.sbspro.2013.12.586

Azman-Saini, W. N. W., Law, S. H., \& Ahmad, A. H. (2010). FDI and economic growth: New evidence on the role of financial markets. Economics Letters, 107(2), 211-213. https://doi.org/10.1016/j.econlet.2010.01.027

Balasubramanyam, V. N., Salisu, M., \& Sapsford. (1996). Foreign Direct Investment and Growth in EP and IS Countries, Economic Journal, 106(434), 92-105.

Barro, R. \& Lee, J. W. (1993). International comparison of educational attainment. Journal of Monetary Economics, 32(3), 361-394.

Baum, C. F., Schaffer, M. E., \& Stillman, S. (2002). Instrumental variables and GMM: estimation and testing. Stata Journal, 3(1), 1-31. https://doi.org/The Stata Journal.

Behera, S. R., Dua, P., \& Goldar, B. (2012). Foreign direct investment and technology spillover: Evidence across Indian manufacturing industries. Singapore Economic Review, 57(2).

Belloumi, M. (2014). The relationship between trade, FDI and economic growth in Tunisia: An application of the autoregressive distributed lag model. Economic Systems, 38(2), 269-287. https://doi.org/10.1016/j.ecosys.2013.09.002

Blomström, M. \& Kokko, A. (1996). The impact of foreign investment on host countries: A review of the empirical evidence. Policy Research Working Paper, 1745.

Borensztein, E., De Gregorio, J., \& Lee, J. W. (1998). How does foreign direct investment affect economic growth? Journal of International Economics, 45(1), 115-135. https:/ / doi.org/10.1016/S0022-1996(97)00033-0

Bosworth, B. \& Collins, S. M. (1999). Capital inflows, investment, and growth. Tokyo Club Papers, 12, 55-74.

Branstetter, L. (2006). Is foreign direct investment a channel of knowledge spillovers? Evidence from Japan's FDI in the United States. Journal of International Economics, 68, 325-344. 
Čadil, J., Petkovová, L., \& Blatná, D. (2014). Human capital, economic structure and growth. Procedia Economics and Finance, 12, 85-92. https://doi.org/10.1016/S2212-5671(14)00323-2

Calvo, M. B. \& Sanchez-Robles, B. (2003). Foreign direct investment, economic freedom and growth: New evidence from Latin America. European Journal of Political Economy, 19(3), 529-545.

Carkovic, M. \& Levine, R. E. (2002). Does foreign direct investment accelerate economic growth?. SSRN Electronic Journal. https://doi.org/10.2139/ssrn.314924

Cheung, K. Y. \& Lin, P. (2004). Spillover effects of FDI on innovation in China: Evidence from the provincial data. China Economic Review, 15(1), 25-44. https://doi.org/10.1016/S1043-951X(03)00027-0

Chung, W. (1998). Up and downstream foreign direct investment and U.S. manufacturing productivity. Academy of Management Proceedings \& Membership Directory, A1-A18.

Denisia, V. (2010). Foreign direct investment theories: An overview of the main FDI theories. European Journal of Interdisciplinary Studies, 2(2), 104-110.

Dormann, C. F., Elith, J., Bacher, S., Buchmann, C., Carl, G., Carré, G., .. Lautenbach, S. (2012). Collinearity: a review of methods to deal with it and a simulation study evaluating their performance. Ecography, 36(1), 27-46.

Driffield, N. (2004). Regional policy and spillovers from FDI in the UK. Annals of Regional Science, 38(4), 579-594. https://doi.org/10.1007/s00168-003-0174-5

Ewe-Ghee, L. (2001). Determinants of, and the relation between, foreign direct investment and growth: A Summary of the recent literature. IMF Working Paper.

Fadhil, M. A. \& Almsafir, M. K. (2015). The role of FDI inflows in economic growth in Malaysia (Time Series: 19752010). Procedia Economics and Finance, 23, 1558-1566. https://doi.org/10.1016/S2212-5671(15)00498-0

Gbakou, M., Jallab, M. S., \& Sandretto, R. (2009). Foreign direct investment, macroeconomic instability and economic growth in MENA countries. GATE Working Paper, 08-17.

Gui-Diby, S. L. (2014). Impact of foreign direct investments on economic growth in Africa: Evidence from three decades of panel data analyses. Research in Economics, 68(3), 248-256. https://doi.org/10.1016/j.rie.2014.04.003

Hansen, L. P. (1982). Large sample properties of generalized method of moments estimators. Econometrica, 50(4), 10291054.

Hansen, L. P., \& Singleton, K. J. (1982). Generalized instrumental variables estimation of nonlinear rational expectations models. Econometrica, 50(5), 1269-1286. https://doi.org/10.2307/1911873

Hanushek, E. A. \& Woessman, L. (2007). The Role of Education Quality in Economic Growth. World Bank Policy Research Working Paper, 4122.

Huchet-bourdon, M., Le Mouël, C., \& Vijil, M. (2011). The relationship between trade openness and economic growth: Some new insights on the openness measurement issue. World Economy, 41(1), 59-76.

Iamsiraroj, S. (2016). The foreign direct investment-economic growth nexus. International Review of Economics \& Finance, 42. https://doi.org/10.1016/j.iref.2015.10.044

Iamsiraroj, S. \& Ulubaşoğlu, M. A. (2015). Foreign direct investment and economic growth: A real relationship or wishful thinking?. Economic Modelling, 51, 200-213. https://doi.org/10.1016/j.econmod.2015.08.009

International Monetary Fund. (1993). Balance of payments manual. Washington, D.C.

Johansson, L. (2015). Does human capital create economic growth in Sub-Saharan Africa?. Sodertorn University.

Kholdy, S. \& Sohrabian, A. (2005). Financial markets, FDI, and economic growth: Granger causality tests in panel data model. EFA 2005 Moscow Meetings.

Li, X. \& Liu, X. (2005). Foreign Direct Investment and economic growth: An increasingly endogenous relationship. World Development, 33(3), 393-407. https://doi.org/10.1016/j.worlddev.2004.11.001

Lin, P. (2002). R \& D in China and the implications for industrial restructuring. CPPS Working Paper Series, 128.

Liu, Z. (2002). Foreign direct investment and technology spillover: Evidence from China. Journal of Comparative Economics, 30(3), 579-602.

Lizondo, J. S. (1991). Foreign direct investment in determinants and systemic consequences of international capital flows. Washington, D.C.

Madariaga, N. \& Poncet, S. (2007). FDI in Chinese cities: Spillovers and impact on growth. The World Economy, 30, $837-62$. 
Makoni, P. L. (2015). An extensive exploration of theories of foreign direct investment. Risk Governance \& Control: Financial Markets \& Institutions, 5(2-1), 77-83. https://doi.org/10.22495/rgcv5i2c1art1

Meo, M. S. A. K. (2016). Panel GMM using STATA.

Moosa, I. A. (2002). Theories of foreign direct investment in foreign direct investment. London: Palgrave Macmillan, $23-67$. https://doi.org/https://doi.org/10.1057/9781403907493_2

Nayak, D. \& Choudhury, R. N. A. (2014). A selective review of foreign direct investment theories. Asia Pacific Research and Training Network on Trade Working Paper Series, 143.

Nunnenkamp, P. \& Spatz, J. (2003). Foreign direct investment and economic growth in developing countries: How relevant are host-country and industry characteristics?. Kiel Working Papers, 1176.

OECD. (2008). OECD benchmark definition of foreign direct investment. OECD publishing, 4(4). https://doi.org/10.1787/9789264045743-en

Ridzuan, A., Ismail, N., \& Che Hamat, A. (2017). Does foreign direct investment successfully lead to sustainable development in Singapore? Economies, 5(3), 29. https://doi.org/10.3390/economies5030029

Roberts, M. R. \& Whited, T. M. (2013). Endogeneity in empirical corporate finance. Handbook of the Economics of Finance, 2, 493-572.

Roodman, D. (2006). How to Do xtabond2: An introduction to difference and system GMM in stata. Central for Global Development Working Paper, 103.

Samad, A. (2009). Does fdi cause economic growth? Evidence from South-East Asia and Latin America. Working Paper, $1(09)$.

Saqib, N., Masnoon, M., \& Rafique, N. (2013). Impact of foreign direct investment on economic growth of Pakistan. Advances in Management and Applied Economics, 3(1), 35-45.

Sargan, J. (1958). The estimation of economic relationships using instrumental variables. Econometrica, 26(3), 393-415.

Schmidheiny, K. (2016). Panel data: Fixed and random effects. Short Guides to Microeconometrics.

Solomon, E. M. (2011). Foreign direct investment, host country factors and economic growth. Ensayos Revista de Economia, 44(1), 41-70.

Sothan, S. \& Zhang, X. (2017). Causality between foreign direct investment and economic growth for Cambodia. Cogent Economics \&Finance, 5(1), 1277860. https://doi.org/10.1080/23322039.2016.1277860

Su, Y. \& Liu, Z. (2016). The impact of foreign direct investment and human capital on economic growth: Evidence from Chinese cities. China Economic Review, 37. https://doi.org/10.1016/j.chieco.2015.12.007

UNCTAD. (2018). World Investment Report 2018.

Vadlamannati, K. C. \& Tamazian, A. (2009). Growth effects of foreign direct investment and economic policy reforms in Latin America. MPRA Paper, 14133.

Vasa, L., \& Angeloska, A. (2020). Foreign direct investment in the Republic of Serbia: Correlation between foreign direct investments and the selected economic variables. Journal of International Studies, 13(1), 170-183. doi:10.14254/2071-8330.2020/13-1/11

Wang, M. (2003). Manufacturing FDI and economic growth: Evidence from Asian economies. Applied Economics, 41(8). https://doi.org/10.1080/00036840601019059

Zekarias, S. M. (2016). The impact of foreign direct investment (FDI) on economic growth in Eastern Africa: Evidence from panel data analysis. Applied Economics and Finance, 3(1), 145-160. https://doi.org/10.11114/aef.v3i1.1317

Zhao, C. \& Du, J. (2007). Causality between FDI and economic growth in China. Chinese Economy, 40(6), 68-82. https://doi.org/10.2753/CES1097-1475400604

Zsohar, P. (2012). Short introduction to the generalized method of moments. Hungarian Statistical Review, 16, 150-170. 